\title{
Effect of chitosan and acetic acid on the shelf life of sea bass fillets stored at refrigerated temperature
}

\author{
Nazrin Sultana Ahmed ${ }^{1 *}$, K. C. Dora ${ }^{2}$, S. Chowdhury ${ }^{2}$, S. Sarkar ${ }^{2}$ and R. Mishra ${ }^{2}$ \\ ${ }^{1}$ Faculty of Fishery Sciences, West Bengal University of Animal and Fishery Siences, Kolkata-700094, INDIA \\ ${ }^{2}$ College of Fisheries, Odisha University of Agriculture and Technology, Berhampur-760007, (Odisha), INDIA \\ *Corresponding author. E-mail: calotropisnaaz@gmail.com \\ Received: November 18, 2016; Revised received: April 19, 2017; Accepted: October 5, 2017
}

\begin{abstract}
Considering the necessity on the use of chitosan and acetic acid as an antimicrobial and antioxidant agents, an attempt was made to study their effect on Asian sea bass fillets stored at refrigerated temperature of $4 \pm 1^{\circ} \mathrm{C}$. The effectiveness of different antimicrobials (Chitosan and Acetic acid) were measured by disk diffusion method against five bacterial strains (E. coli, Vibrio parahaemolyticus, Staphylococcus aureus, Proteus mirabilis and Pseudomonas fragi) with $1 \%$ Acetic acid as $\left(\mathrm{T}_{1}\right), 1 \%$ Acetic acid $+1 \%$ Chitosan as $\left(\mathrm{T}_{2}\right), 1 \%$ Acetic acid $+2 \%$ Chitosan as $\left(\mathrm{T}_{3}\right)$ and distilled water as control $(\mathrm{C}) . \mathrm{T}_{2}$ was more effective in inhibiting all the bacteria except Pseudomonas fragi. Treatment $T_{1}$ was found to be more effective against it whereas the action of $T_{3}$ on the bacterial strains was also effective but less than the other two treatments. Further, antioxidant property of the treatments were measured by DPPH method which indicated that $\mathrm{T}_{3}$ showed highest $\%$ of antioxidative activity (3.94\%) followed by $\mathrm{T}_{1}$ $(3.85 \%), \mathrm{T}_{2}(2.62 \%)$, and $\mathrm{C}(1.788 \%)$. Thus, it is observed that the antioxidant activity was found to be increased with the increasing concentration of chitosan. Application of chitosan and acetic acid coatings on Asian sea bass (Lates calcarifer) fillets successfully controlled the TVB-N values, PV and TBA values $(p<0.05)$ when compared to control sample and among all the treatments $T_{2}$ was found to be the best. Coating of chitosan and acetic acid on the fillets also resulted in improvement of sensory scores as well as acceptability under refrigerated condition.
\end{abstract}

Keywords: Acetic acid, Antimicrobial, Antioxidant, Chitosan, Seabass

\section{INTRODUCTION}

Sea bass (Lates calcarifer) is a widely valued fish species that is consumed as a whole or, in filleted form and is one of the major farmed brackish water fish species in Odisha and West Bengal. It has white flesh, mild taste and low fat content (Body et al., 1992). Because of its high market value, it is required to extend the shelf life of the refrigerated or frozen product. Simple refrigeration or freezing is not enough to prevent lipid oxidation, rancid off-flavour or, bacterial growth which may cause high risk for consumer health. There are many well-recognized processing technologies developed worldwide in the field of food science and technology and being commercialized now -a-days for conversion of raw materials into various edible food products. These technologies have gained the worldwide acknowledgement for their potential and versatile applications. Moreover, the growing consumers demand for fresh, safe, chemical, additive or preservative free and minimally processed foods has insisted the food scientists and technologists to develop many non-thermal food processing technologies which cause minimum nutritional and sensory qualities impairment in the processed foods (Dalai,2010).Use of chitosan as bio-preservative is a new promising tech- nology developed to kill/ inactivate undesirable microorganisms in more environmental friendly way without affecting the food preservation (Fan et al., 2009). Chitosan a poly- $\beta$-(1-4)-2-amino-2-deoxy-Dglucopyranose is a deacetylated product of chitin $\beta$ - (14)-2-acetamido-2-deoxy-D-glucan which is a structural polysaccharide found in crustacean, insects and some fungi. Chitosan can be characterized in terms of its quality, intrinsic properties such as purity, molecular weight, viscosity, degree of deacetylation (DD) and physical forms. The inclusion of chitosan and acetic acid as bio-preservative was considered as safe by the Codex Alimentarius Commission in 2003 as these compounds are non-toxic and have no long term effects on human health (Aranaz et al., 2009). With this backdrop, an attempt was made to study the effect of chitosan and acetic acid as an anti-microbial and antioxidant agent on sea bass fillets stored at refrigerated temperature of $4 \pm 1^{\circ} \mathrm{C}$.

\section{MATERIALS AND METHODS}

Freshly caught sea bass (Lates calcarifer) with an average weight of $500 \mathrm{~g}$ was procured from market and transported to fish processing laboratory in iced condition in an insulated box. They were processed immediately under hygienic and sanitary condition to prevent 
any further contamination. The study was conducted during 2014-15.

Fish processing: Fishes were beheaded and de-scaled following which de-skinned fillets were prepared weighing about 50 to $70 \mathrm{~g}$ under good hygienic and sanitary condition. Fresh skinless fillets of seabass were rinsed in an ice water bath $(1: 1$, tap water: crushed ice). The rinsed fillets were then divided into 4 groups and subjected to 4 treatments, including Fillets with distilled water Control (C), Fillets with $1 \%$ Acetic acid $\left(\mathrm{T}_{1}\right)$, Fillets with $1 \%$ Acetic acid $+1 \%$ Chitosan $\left(\mathrm{T}_{2}\right)$ and Fillets with $1 \%$ Acetic acid $+2 \%$ Chitosan $\left(\mathrm{T}_{3}\right)$. The treatments were applied by immersing the fillets in the solution for 60 seconds. All the treated samples were packed in Low density polyethylene bags, heat sealed and stored at a refrigerated temperature of $4 \pm 1^{\circ} \mathrm{C}$ for 15 days. The samples were collected at every 3 days interval and analysed for different physical, biochemical, microbiological and sensory parameters.

Detection of chitosan and acetic acid as antimicrobial agent in different concentrations against selected bacterial strains: The effectiveness of an antimicrobial agent against indicator bacteria was detected following the method of Kirby-Bauer diskdiffusion (Johnson and Case, 1995). Five numbers of indicator organisms selected for the purpose were Staphylococcus aureus (ATCC 25923), Pseudomonas fragi (MTCC 510), Proteus mirabilis (MTCC 45), Vibrio parahaemolyticus (MTCC 451) and Escherichia coli (MTCC 40) whose incubation temperatures were $37^{\circ} \mathrm{C}, 25^{\circ} \mathrm{C}, 25^{\circ} \mathrm{C}, 37^{\circ} \mathrm{C}$ and $37^{\circ} \mathrm{C}$ respectively. The bacteria of interest were swabbed uniformly across a culture plate. Then a filter-paper disk, impregnated with the compound to be tested, was placed on the surface of the agar. The compound diffuses out from the filter paper into the agar. The concentration of the compound will be higher next to the disk and will decrease gradually as distance from the disk increases. If the compound is effective against bacteria at a certain concentration, no colony will grow wherever the concentration in the agar is greater than or equal to that effective concentration. This region is called the "zone of inhibition." Thus, the size of the zone of inhibition was measured for the compound's effectiveness: the larger the clear area around the filter disk, more is the effectiveness of the compound.

This method was used to compare the effectiveness of different antimicrobials (Chitosan and Acetic acid) at different concentrations ( $1 \%$ and $2 \%$ ) against mentioned bacterial strains. Since this method depends on diffusion of the compound, it is necessary to keep several factors constant while making comparisons such as the size of the filter disks, the temperature of incubation, the composition of nutrient agar and its thickness and the uniformity of bacterial plating.
Detection of antioxidant property of chitosan and acetic acid in different concentrations: The free radical scavenging activities of each fraction was analysed using a stable DPPH (Diphenylpicrylhydrazyl) (Blois, 1958). The reaction mixture containing $1.8 \mathrm{ml}$ of $0.1 \mathrm{mM}$ DPPH and $0.2 \mathrm{ml}$ of each serial dilution $(0.5$ to 2) of different concentrations of chitosan and acetic acid was measured keeping distilled water as control. The reaction mixture was allowed to incubate for 5 minutes at room temperature in the dark and scavenging activity of each sample was quantified by decolorization at $515 \mathrm{~nm}$.

Equation 1:\% inhibition of DPPH radical = Abs.of control - Absiof sample Abs.of control

$x 100$

Determination of fillet yield and proximate composition: Fillet yield \% was determined according to Thorarinsdottir et al. (2004). The proximate composition of fish fillet such as moisture content, protein content, fat content and ash content were assessed following the method of A.O.A.C. (1995).

Determination of quality parameters: The chemical characteristics like total volatile base nitrogen (TVB$\mathrm{Nmg} \%$ ), peroxide value (PVmeq $\mathrm{O}_{2} / \mathrm{kg}$ of fat), thiobarbituric acid (TBAmg malonaldehyde/ $\mathrm{kg}$ ), protein solubility (\%) and $\mathrm{pH}$ of the samples were analysed following the method of A.O.A.C. (1995).

Microbiological characteristics such as total plate count (TPC cfu/gm) of filletsampleswere carried out as per the Standard method of APHA (1998).Sensory evaluation of the fish fillet samples for colour, odour, texture and overall acceptability was carried out by highly experienced judges on a 9-point hedonic scale following the method of Larmond (1977).The statistical analysis of data wasmade following two- way Analysis of Variance (ANOVA) using statistical tools of MS Excel software.

\section{RESULTS AND DISCUSSION}

Antimicrobial property of chitosan and acetic acid in different concentrations: The present study of antimicrobial assay indicated clear zones of inhibition around all the samples except $\mathrm{C}$ (Table 1). The samples $\mathrm{T}_{1}, \mathrm{~T}_{2}$ and $\mathrm{T}_{3}$ showed zone of inhibition of 4.2 $\mathrm{mm}, 8.3 \mathrm{~mm}$ and $7.0 \mathrm{~mm}$ respectively against $E$. coli after 24 hours of incubation at $37^{\circ} \mathrm{C}$ leading to the inference that $\mathrm{T}_{2}(1 \%$ acetic acid $+1 \%$ chitosan) showed highest zone of inhibition. Similarly $\mathrm{T}_{2}$ sample showed highest zone of inhibition against Staphylococcus aureus (10.1 mm), Vibrio parahaemolyticus $(10.0 \mathrm{~mm})$, and Proteus mirabilis $(12.6 \mathrm{~mm})$.Thus, it is evident that $\mathrm{T}_{2}(1 \%$ acetic acid $+1 \%$ chitosan $)$ gave the best inhibitory effect $(p<0.05)$ in comparison to other concentrations of chitosan and acetic acid.

Acetic acid, an organic compound with acidic properties, is used in food preservation because of its effect 


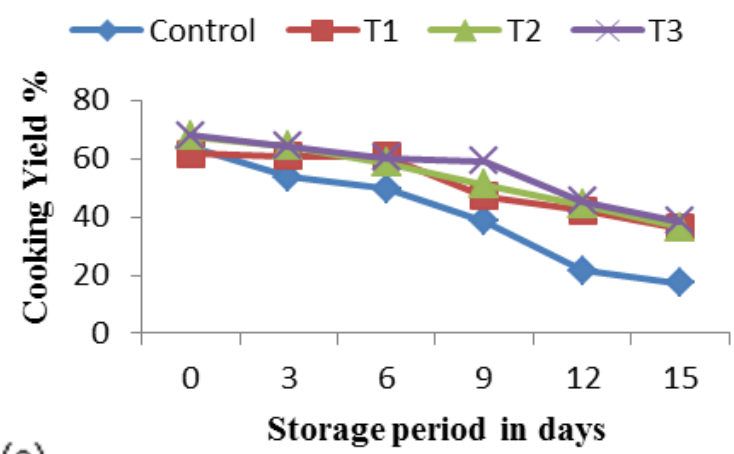

(a)
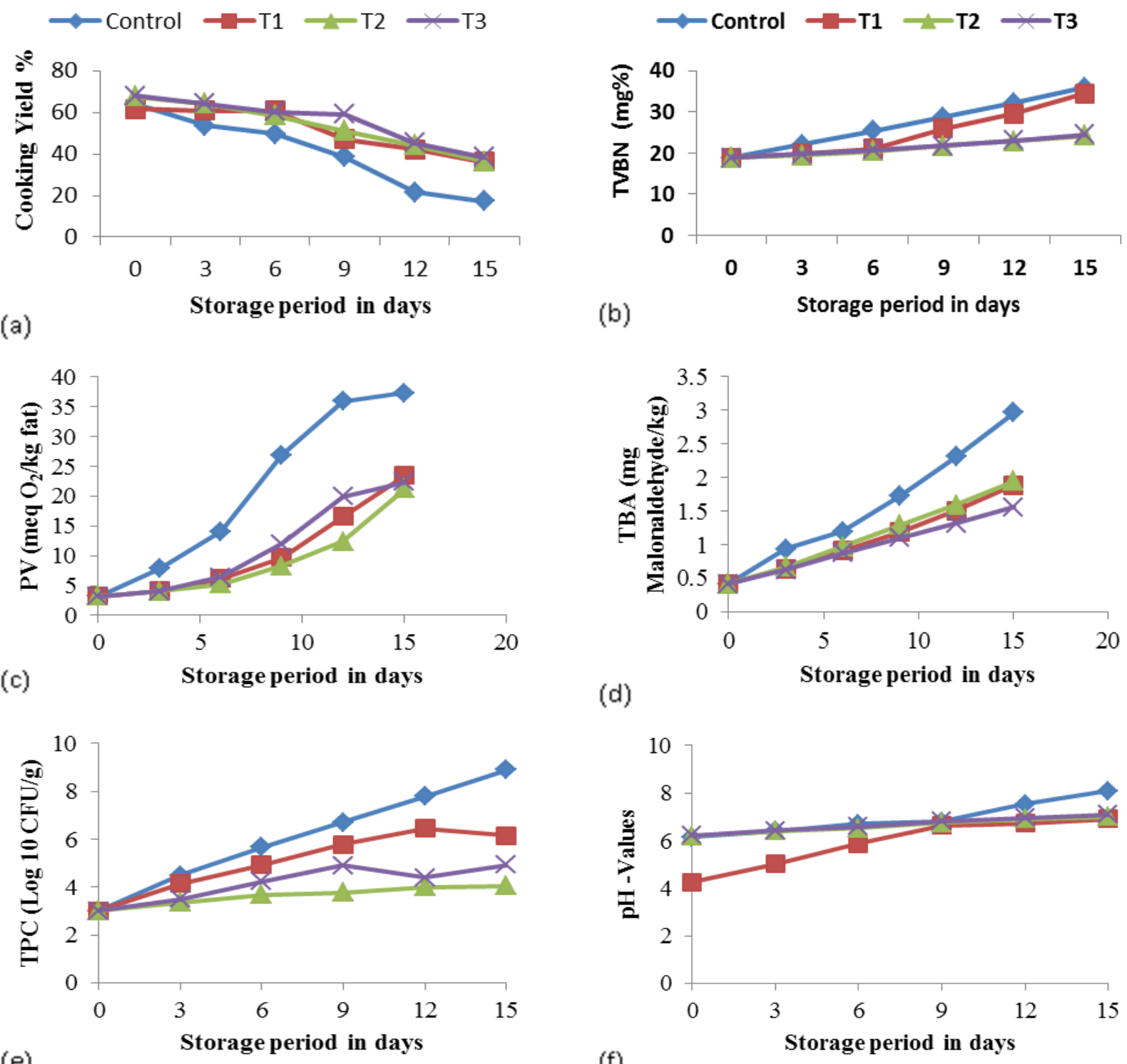

(d)

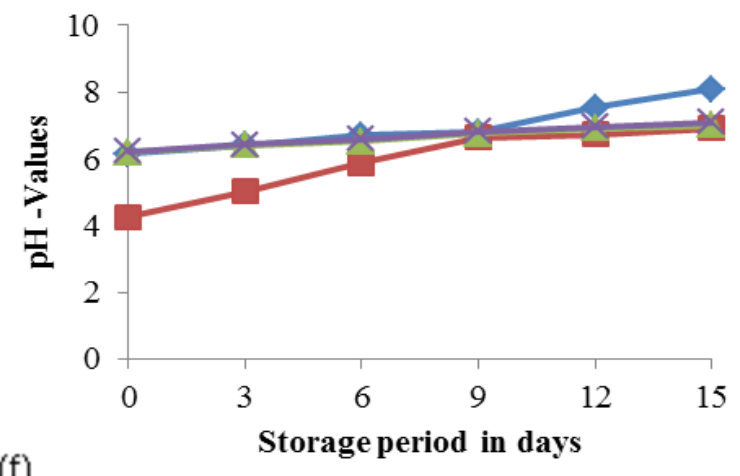

Fig. 1. Changes in various parameters of sea bass fillets treated with distilled water $(C), 1 \%$ acetic acid $\left(T_{1}\right), 1 \%$ acetic acid $+1 \%$ chitosan $\left(T_{2}\right)$ and $1 \%$ acetic acid $+2 \%$ chitosan $\left(T_{3}\right)$ at refrigerated storage of $(4 \pm 1){ }^{\circ} \mathrm{C}$.

on bacteria. The basic principle on the mode of action of acetic acid is the non ionized form which can penetrate the bacteria cell wall and disrupt the normal physiology of certain types of bacteria (Fan et al., 2009). The acetic acid either chemically pure or as Vinegar, had a marked influence on the growth of different types of bacteria. At constant $\mathrm{pH}$, greater inhibition was obtained with an increasing concentration of acetic acid. The $\mathrm{pH}$ is one of the important factors which influences the growth of bacteria. It has been well established that most microorganisms grow best at $\mathrm{pH}$ values around 7 , therefore, $\mathrm{pH}$ reduction is one of the inhibitory factors, which can limit the growth of bacteria. Upon passive diffusion of acetic acid into the bacteria, where the $\mathrm{pH}$ is near or above neutrality, and the acid will dissociate and lower the bacteria internal $\mathrm{pH}$, leading to situation that will impair or stop the growth of bacteria. On the other hand, the anionic part of the organic acid that cannot escape the bacteria in its dissociated form will accumulate within the bacteria and disrupt many metabolic functions, leading to osmotic pressure increase incompatible with the survival of the bacteria(Ewadh et al.,2013).

Kong et al. (2010) showed that chitosan and its derivatives are more powerful antibacterial agent against Gram negative bacteria than Gram-positive microorganism which corroborates with the results of present study. No et al., (2002) reported that $1 \%$ chitosan concentration can retard gram negative bacteria like $E$. coli, Salmonella and Vibrio. However, it is very important to mention that chitosan is soluble only in acidic media and therefore, the effect of $\mathrm{pH}$ on microor- 
Nazrin Sultana Ahmed et al. / J. Appl. \& Nat. Sci. 9 (4): 2175 -2181 (2017)

Table 1. Antimicrobial property of chitosan and acetic acid at different concentrations.

\begin{tabular}{llllll}
\hline Bacterial strains & $\mathbf{C}(\mathbf{m m})$ & $\mathbf{T}_{\mathbf{1}}(\mathbf{m m})$ & $\left.\mathbf{T}_{\mathbf{2}} \mathbf{( m m}\right)$ & $\mathbf{T}_{\mathbf{3}}(\mathbf{m m})$ \\
\hline Escherichia coli (MTCC 40) & 0 & $4.26 \pm 0.13$ & $8.366 \pm 0.08$ & $7.02 \pm 0.22$ \\
Vibrio parahaemolyticus (MTCC 451) & 0 & $2.36 \pm 0.41$ & $10.02 \pm 0.14$ & $8.33 \pm 0.19$ \\
Staphylococcus aureus (ATCC 25923) & 0 & $4.51 \pm 0.03$ & $10.15 \pm 0.24$ & $9.52 \pm 0.22$ \\
Proteus mirabilis (MTCC 45) & 0 & $9.36 \pm 0.24$ & $12.64 \pm 0.09$ & $9.86 \pm 0.17$ \\
Pseudomonas fragi (MTCC 510) & 0 & $8.33 \pm 0.20$ & $6.00 \pm 0.17$ & $4.82 \pm 0.11$ \\
\hline
\end{tabular}

*Results are mean of three determinations ( $n=5)$ with S.D.

Table 2. Antioxidant property (\% inhibition) of chitosan and acetic acid at different concentrations.

\begin{tabular}{lc}
\hline Sample & \% inhibition \\
\hline Control $(\mathrm{C})$ & 1.788 \\
$1 \%$ Acetic acid $\left(\mathrm{T}_{1}\right)$ & 3.859 \\
$1 \%$ Acetic acid $+1 \%$ Chitosan $\left(\mathrm{T}_{2}\right)$ & 2.62 \\
$1 \%$ Acetic acid $+2 \%$ Chitosan $\left(\mathrm{T}_{3}\right)$ & 3.94 \\
\hline
\end{tabular}

Table 3. Proximate composition analysis of Lates calcarifer.

\begin{tabular}{ll}
\hline Parameters & Values \pm S.D. \\
\hline Moisture (\%) & $77.38 \pm 0.36$ \\
Protein (\%) & $19.75 \pm 0.17$ \\
Fat (\%) & $1.22 \pm 0.05$ \\
Ash (\%) & $1.17 \pm 0.01$ \\
\hline
\end{tabular}

*Results are mean of three determinations $(n=5)$ with S.D.

ganisms must be considered together with the effect of chitosan. Thus, the synergetic effect of chitosan $/ \mathrm{pH}$ together is probably the most evident explanation of the antimicrobial effect of chitosan.

Similarly, $1 \%$ chitosan $+1 \%$ acetic acid $\left(\mathrm{T}_{2}\right)$ has shown more inhibitory effect but in case of Pseudomonas fragi, $1 \%$ acetic acid $\left(\mathrm{T}_{1}\right)$ has shown maximum zone of inhibition with a zone diameter of $8.3 \mathrm{~mm}$. Organic acids are generally recognized as safe (GRAS) antimicrobial agents, and the dilute solutions of organic acids (1 and $3 \%$ ) are generally without any effect on desirable sensory properties during preservation of many products from contaminated pathogenic bacteria.

Antioxidant property of chitosan and acetic acid in different concentrations: In the present study, the DPPH Radical Scavenging Assay test (Table 2) indicated that $1 \%$ acetic acid $+2 \%$ chitosan $\left(\mathrm{T}_{3}\right)$ showed highest $\%$ of antioxidative(3.94\%) followed by $\mathrm{T}_{1}$ $(3.85 \%), \mathrm{T}_{2}(2.62 \%)$, and $\mathrm{C}(1.788 \%)$. Thus, it is observed that the antioxidant activity was found to be increasing with the increase in the concentration of chitosan.

Along with the growing consumer demand for seafood devoid of synthetic antioxidants, chitosan has been a booming antioxidant agent in fish and shellfish. Kim and Thomas (2007) observed that the antioxidative effect of chitosan in salmon was molecular weight (tested at $\mathrm{MW}=30,90$ and $120 \mathrm{kDa}$ ) dependent and concentration (evaluated at $0.2 \%, 0.5 \%$ and $1 \% \mathrm{w} / \mathrm{w}$ ) dependent. The authors reported that the $30 \mathrm{kDa}$ chitosan showed the highest radical-scavenging activity.

Effect of chitosan and acetic acid on Asian sea bass fillets
Fillet yield \%: Fish fillet, as the main edible portion of fish, holds the main economic and nutritional interest of fish production. Increasing fillet yield, without any negative effect on flesh quality, is a major challenge for fish farmers. The fillet yield of the sea bass in the present study was found to be $40.5 \%$ which corroborates with the findings of Kyrana and Lougovois (2002). The proximate composition of sea bass fillets was presented in Table 3.

Cooking yield \%: The cooking yields of the sea bass fillet samples $\mathrm{C}$ (distilled water), $\mathrm{T}_{1}, \mathrm{~T}_{2}$ and $\mathrm{T}_{3}$ were $64.02 \%, 61.75 \%, 67.83 \%$ and $67.89 \%$ in the initial day (Fig. 1a) which reduced to $17.22 \%, 36.10 \%, 36.54 \%$ and $38.52 \%$ respectively during refrigerated storage of 15 days. Although cooking yield of control sample was lowest among all other treated samples, there was no significant difference among the rest three samples during the storage period $(\mathrm{P}<0.05)$. It is known that storage time had stronger effect on cooking yield. But in the present study chitosan coating through treatment significantly reduced weight loss of fresh sea bass $(\mathrm{p}<$ 0.05 ) which could be because of the chitosan film/ polymer formed on the surface that delayed migration of moisture from the food surface into the environment (Sakthivel et al., 2007). They reported that chitosan coatings may act as moisture-sacrificing agents instead of moisture barriers which reduced the weight loss. This might be due to polymers such as chitosan with high crystallinity. They are usually less permeable due to their ordered structure, and that the mass transfer of gas in a semi-crystalline polymer is primarily a function of the amorphous phase (Miller and Krochta, 1997).

Total volatile base nitrogen (TVB-N): TVB-N is widely used as an indicator of quality deterioration and the increase in its value is related to the activity of spoilage bacteria and endogenous enzymes (Kyrana and Lougovois, 2002). According to them, fish are usually regarded as spoiled at a level of $30 \mathrm{mg} \%$ TVB$\mathrm{N}$ content. In this study, the initial TVB-N value was $18.87 \mathrm{mg} \%$ (Figure $1 \mathrm{~b}$ ), which was within the recommended limit. In case of control sample TVB-N value increased to $32.2 \mathrm{mg} \%$ after 12 days of storage, whereas $\mathrm{T}_{2}$ and $\mathrm{T}_{3}$ samples did not reach the limit of $30 \mathrm{mg} \%$ even after 15 days of storage. This may be due to the faster reduction in bacterial population with decrease in oxidative deamination of non-protein nitrogen compounds, in presence of chitosan in fish samples. In ad- 
Table 4. Changes in Protein Solubility (\%) of treated sea bass fillets at $4 \pm 1{ }^{\circ} \mathrm{C}$.

\begin{tabular}{lcccc}
\hline Days of storage & $\mathbf{C}(\mathbf{\%})$ & $\mathbf{T}_{\mathbf{1}} \mathbf{( \% )}$ & $\mathbf{T}_{\mathbf{2}} \mathbf{( \% )}$ & $\mathbf{T}_{\mathbf{3}} \mathbf{( \% )}$ \\
\hline 0 & $86.6 \pm 0.5$ & $86.6 \pm 0.5$ & $86.6 \pm 0.5$ & $86.6 \pm 0.5$ \\
3 & $85.5 \pm 1.7$ & $85.53 \pm 0.2$ & $85.42 \pm 1.3$ & $85.59 \pm 0.5$ \\
6 & $90.2 \pm 3.4$ & $89.02 \pm 0.5$ & $87.41 \pm 3.4$ & $87.35 \pm 0.16$ \\
9 & $85.2 \pm 1.9$ & $88.03 \pm 1.2$ & $86.53 \pm 0.3$ & $86.92 \pm 0.54$ \\
12 & $71.6 \pm 1.7$ & $83.29 \pm 1.7$ & $83.29 \pm 1.9$ & $82.54 \pm 0.88$ \\
15 & $64.3 \pm 0.5$ & $72.6 \pm 1.9$ & $73.29 \pm 3.1$ & $74.52 \pm 0.42$ \\
\hline
\end{tabular}

*Results are average value of five determinants $(\mathrm{n}=5)$ with standard deviation, Distilled water Control (C), Fillets with $1 \%$ Acetic acid $\left(\mathrm{T}_{1}\right)$, Fillets with $1 \%$ Acetic acid $+1 \%$ Chitosan $\left(\mathrm{T}_{2}\right)$ and Fillets with $1 \%$ Acetic acid $+2 \%$ Chitosan $\left(\mathrm{T}_{3}\right)$

dition, Lopez-Caballero et al. (2005) observed that the protective chitosan- gelatin coating distinctly lowered TVB-N values, and hence brought down the rate of spoilage.

Peroxide value (PV): Oxidative rancidity is one of the most important factors that determine the acceptability of the fish during processing and storage. Lakshmann (2000) stated that the peroxide value is a measure of the first stage of oxidative rancidity and recommended a level of PV in seafood is $10-20$ meq $\mathrm{O}_{2} / \mathrm{kg}$ of fat as a limit of acceptability. In the present study, all the samples were under acceptable limit when stored at $4 \pm 1^{\circ} \mathrm{C}$ till $12^{\text {th }}$ day except the control $\left(26.9 \mathrm{meq} \mathrm{O}_{2} / \mathrm{kg}\right.$ of fat $)$ (Fig. 1c). The sample $\mathrm{T}_{2}$ with lower concentration of chitosan showed more inhibitory effect on primary oxidation observed with a PV of 21.24 meq $\mathrm{O}_{2} / \mathrm{Kg}$ fat during 15days of storage, whereas the value for PV in all of the treated samples were found to be marginally on higher side. The increase in PV value is attributed to the oxidation of highly unsaturated fatty acids in fish lipids by the catalytic activity of common salt, iron impurities that are probably present in the crude salt, pro-oxidant action of moisture and auto-oxidation by atmospheric oxygen. The result of the present study corroborates with the findings of Kyrana and Lougovois (2002).

Thiobarbutric acid (TBA): TBA as a quality index is widely used as an indicator for the assessment of the degree of lipid oxidation (Cakli et al., 2006). They suggested that the indicative of a good quality fish has a maximum TBA value of $5 \mathrm{mg}$ malonaldehyde $/ \mathrm{kg}$, while fish may be consumed up to a TBA value of 8 $\mathrm{mg}$ malonaldehyde $/ \mathrm{kg}$ and with respect to off-odours, TBA value of at least $2.0 \mathrm{mg}$ malonaldehyde $/ \mathrm{kg}$ is required for perception of rancid odours. In the present study, TBA value was found to be exceeding $5 \mathrm{mg}$ $\mathrm{MA} / \mathrm{kg}$ and in case of treated samples, sample $\mathrm{T}_{3}$ showed the best result followed by sample $T_{1}$ and $T_{2}$ (Fig. 1d). The low TBA values obtained in the present study could be due to the low crude lipid content in fresh sea bass at the beginning of the experiment. During storage period, lipid auto-oxidation was found to be insignificant $(p>0.05)$. In this study, a sharp increase in TBA content was observed from $9^{\text {th }}$ day onwards which was probably due to the destruction of hydro-peroxides into secondary oxidation products, especially aldehydes in the later stages of lipid oxidation (Chaijan et al., 2006).

Protein solubility: Solubility of protein is considered as the most important factor and an excellent index for their functionality of dehydrated products. In addition, solubility has its relevance to other properties such as viscosity, gelation, foaming and emulsification. Protein Solubility refers to the amount of total muscle protein that goes into solution under specified conditions (Lakshmann, 2000) and depends on protein structure, $\mathrm{pH}$, concentration of salt, temperature, duration of extraction and many other intrinsic factors. In the present study, the initial protein solubility of all the samples was $86.6 \%$ which decreased to $64.3 \%, 68.4 \%$, $74.2 \%$ and $70.5 \%$ in case of control, $\mathrm{T}_{1}, \mathrm{~T}_{2}$ and $\mathrm{T}_{3}$ respectively during storage period of 15 days at refrigerated temperature of $4 \pm 1^{\circ} \mathrm{C}$ (Table 4). Sample $\mathrm{T}_{1}$ showed the lowest solubility while $\mathrm{T}_{2}$ gave the highest solubility followed by $\mathrm{T}_{3}$ during the storage period. Decrease in solubility indicated protein denaturation during low temperature storage period. Geirsdottir et al. (2007) had also reported protein solubility of washed herring muscle at $\mathrm{pH} 11$ which decreased significantly from $87 \%$ to $72 \%$ during 20 days of refrigerated storage.

pH: The initial $\mathrm{pH}$ values of fish samples such as control, $\mathrm{T}_{1}, \mathrm{~T}_{2}$ and $\mathrm{T}_{3}$ were $6.1,4.2,6.2$ and 6.2 which increased to $6.6,6.9,6.7$ and 6.9 respectively during refrigerated storage (Fig. 1f) .The initial reduction in $\mathrm{pH}$ value may be due to the synergistic effect of both $\mathrm{pH}$ value of immersion solutions and the formation of lactic acid from glycogen in fish meat (Li et al., 2012). However, low initial $\mathrm{pH}$ value of sample $\mathrm{T}_{1}$ may be because of the acetic acid coating which is in agreement with Lu et al. (2012). The increasing $\mathrm{pH}$ value during storage may be due to accumulation of alkaline compounds, such as ammonia and trimethylamine mainly derived from microbial action during fish muscle spoilage as reported by Jeon et al. (2002). The acceptable upper limit for the $\mathrm{pH}$ of fish is 6.8-7.0. In the present study, $\mathrm{pH}$ values of all the samples were well within the acceptable limit during the storage period.This might be due to antimicrobial effects of chitosan and inhibitory activity on the endogenous proteases which may have delayed the increase in $\mathrm{pH}$ and reduced the changes in the quality of the samples (Fan et al., 2009). 
Microbiological analysis: Seafood provides a good niche for growth of different microorganisms. The initial Total Plate Count (TPC) of sea bass fillet samples were $3.02 \log \mathrm{CFU} / \mathrm{gm}$ (Figure $1 \mathrm{e}$ ) indicating very good quality of raw sea bass fillet which increased to 8.91, 6.16, 4.06 and $4.93 \mathrm{log} \mathrm{CFU} / \mathrm{g}$ in control, $\mathrm{T}_{1}, \mathrm{~T}_{2}$ and $\mathrm{T}_{3}$ during 15 days refrigerated storage period respectively. Although control sample increased the acceptable limit of $7.0 \log 10 \mathrm{CFU} / \mathrm{gm}$ (ICMSF, 2005) during storage, all other samples were well within the limit and $\mathrm{T}_{2}$ coating was more effective than other samples. The chitosan and acetic acid coatings might be responsible for lowering the TPC of fish fillet samples significantly $(\mathrm{P}<0.05)$. Lopez-Caballero et al. (2005) reported that a chitosan coating consisting a blend of acetic acid and $1 \%$ chitosan exerts an inhibitory effect on the gram-negative flora of fish patties since non-ionized acetic acid penetrates the bacteria cell wall and disrupt the normal physiology of certain types of bacteria that presented as $\mathrm{pH}$ - sensitive, meaning that they cannot tolerate a wide internal and external $\mathrm{pH}$ gradient.

Sensory characteristics: Sensory evaluation is an important tool for assessing the quality of fish and fishery products and thereby their acceptability (Cao et al., 2009).Sensory evaluation of food is defined as the scientific means of quantifying and interpreting the variations in food characteristics (Color, odour, taste, texture, appearance and overall acceptability) by using human senses of sight, smell, taste, touch and hearing. Studies have shown that assessment of food freshness/ characteristics using sensory methods are capable of giving objective and / reliable results when assessments are done under controlled conditions. Generally, trained and experienced taste panel is essential to obtain accurate and reproducible result. In the present study, the overall acceptability (OAA) of the control, $\mathrm{T}_{1}, \mathrm{~T}_{2}$ and $\mathrm{T}_{3}$ samples was 8.29 initially which was organoleptically acceptable and during refrigerated storage for 15 days it declined gradually to $3.74,4.60$, 6.42 and 5.95 respectively. The long storage life of fillets coated with $1 \%$ acetic acid and $1 \%$ chitosan could be attributed to its different functional properties i.e. antioxidant, antimicrobial and oxygen barrier as suggested by Fan et al. (2009).

\section{Conclusion}

Chitosan is a versatile material with proved antimicrobial as well as antioxidant activity. In the present study, sample $\mathrm{T}_{2}(1 \%$ Acetic acid $+1 \%$ Chitosan) gave the best result (4.60) considering the sensory quality of the product and the sample was found to be acceptable even at the end of storage period of 15 days. There is an increased interest in development and use of Antimicrobial Edible Film and Coating to preserve food maintaining good quality along with longer shelf-life and food safety which is based on consumers demand for natural and safe products. From the findings of the research work, it may however be concluded that chitosan and acetic acid may be considered as good biopreservatives which would be beneficial to the consumers in the long run.

\section{REFERENCES}

A.O.A.C. (Association of Analytical Chemists) (1995). Standard Official Methods of Analysis of the Association of Analytical Chemists. $14^{\text {th }}$ edition, S.W. Williams (Ed), Washington, DC. P.121

APHA (1998). Compendium of methods for the microbiological examination of foods (Ed.) M.L. Speak, APHA, New York, 701

Aranaz, I., Mengíbar, M., Harris, R., Paños, I., Miralles, B., Acosta, N. and Heras, Á. (2009). Functional characterization of chitin and chitosan. Current Chemical Biology, 3(2):203-230

Blois, M.S.( 1958). Antioxidant determinations by the use of a stable free radical. Nature. 29:1199 1200

Body, L. C., Green, D. P. and LePors, L. A. (1992). Quality changes of pond-raised hybrid striped bass during chill pack and refrigerated storage. Journal of Food Science, 57(1):59-62

Cakli, S., Kilinc, B., Cadun, A., Dincer, T. and Tolasa, S. (2006).Effects of gutting and ungutting on microbiological, chemical, and sensory properties of aquacultured sea bream (Sparus aurata) and sea bass (Dicentrarchus labrax) stored in ice. Food Sci Nutr., 46: 519-527

Cao, R., Xue, C. H., Liu, Q. and Xue, Y. (2009). Microbiological, chemical, and sensory assessment of Pacific oysters (Crassostrea gigas) stored at different temperatures. Czech J Food Sci., 27(2):102-108

Chaijan, M., Benjakul, S., Visessanguan, W. and Faustman, C. (2006). Changes of lipids in sardine (Sardinella gibbosa) muscle during iced storage. Food Chemistry. 99: 83-91

Dalai, S. R. and Sahu, J. K. (2010). High Hydrostatic Pressure (HPP) in Food Processing: Design Aspects and Applications. Assam University Journal of Science and Technology, 6(2):70-87

Ewadh,M., Hasan,H., Bnyan,I., Mousa,F., Sultan,J. and Ewadh,M. (2013).Antibacterial Activity of 2- (2-Hydroxy phenylimino) Acetic Acid. Life Sci. Technol., 7:15-20

Fan,W., Sun, J., Chen, Y., Qiu, J., Zhang, Y. and Chi, Y. (2009). Effects of chitosan coating on quality and shelf life of silver carp during frozen storage. Food Chem. 115: 66-70

Geirsdottir,M., Hlynsdottr,H., Horkelsson, G. and Sigurgisladottir, S. (2007). Solubility and viscosity of Herring (Clupea harengus) proteins as affected by freezing and frozen storage. Journal of food science, 72:376-380

Jeon, Y. J., Kamil, J. Y. V. A. and Shahidi, F. (2002). Chitosan as an edible invisible film for quality preservation of herring and Atlantic cod. Journal of Agricultural and Food Chemistry, 50(18): 5167-5178

Johnson, T. and Case, C. (1995). Chemical Methods of Control," adapted from Laboratory Experiments in Microbiology, Brief Edition, 4th ed. Redwood City, CA: Benjamin/Cummings p. 345

Kim, K.W. and Thomas, R.L. (2007). Antioxidant role of chitosan in a cooked cod (Gadus morhua) model sys- 
tem. Journal of Food Lipid., 9:57-64

Kong, M., Chen, X.G., Xing, K. and Park, H.J. (2010). Antimicrobial activity of chitosan andmode of action: A state of art review. International Journal of Food Microbiology, 144:51-63

Kyrana, V. R. and Lougovois, V. P. (2002). Sensory, chemical and microbiological assessment of farm-raised European sea bass (Dicentrarchus labrax) stored in melting ice. International Journal of Food Science and Technology, 37(3):319-328

Lakshmann, P.T. (2000). Fish spoilage and quality Assessment, In: Quality Assessment in Seafood Processing. CIFT and SOFT (India) Publication. 26-40

Larmond, E. (1977). Laboratory methods for sensory evaluation of food. Canada Department of Agriculture Publication.1637-1662

Li, T. T., Hu,W. Z., Li, J. R., Zhang, X. G., Zhu, J. L. and Li, X. P. (2012). Coating effects of tea polyphenol and rosemary extract combined with chitosan on the storage quality of large yellow croaker (Pseudosciaena crocea). Food Control.25: 101-106

Lopez-Caballero, M. E., Gómez-Guillén, M. C., Pérez Mateos, M. and Montero, P. (2005). A chitosan-gelatin blend as a coating for fish patties. Food Hydrocolloids.19(2) : 303-311

Lu, F., Liu, S. L., Liu, R., Ding, Y. C. and Ding, Y. T. (2012). Combined effect of ozonized water pretreatment and ozonized flake ice on maintaining quality of Japanese sea bass (Lateolabrax japonicus). Journal of Aquatic Food Product Technology.21:168-180

Miller, K.S. and Krochta, J. M. (1997). Oxygen and aroma barrier properties of edible films: a review. Trends Sci. Technol. 8: 228-237

No, H. K., Cho,Y. I., Kim, H. R. and Meyers, S.P. (2002). Antimicrobial activity of chitosan and chitosan oligomers with different molecular weights. Journal of Food Microbiology. 74:65-72

Sakthivel, S., Liu, Q., Huang, J. and Prinyawiwatkul, W. (2007). The influence of chitosan glazing on the quality of skinless pink salmon (Oncorhynchus gorbuscha) fillets during frozen storage. Journal of Food Eng., 83:366-373

Thorarinsdottir, K. A., Arason, S., Bogason, S.G. and Kristbetrgsson, K.(2004). The effects of various salt concentrations during brine curing of cod. International journal of food science and technology. 39:79-89 